\title{
FERTILIZING PROPERTIES OF UREA-MAGNESIUM SLOW- RELEASE FERTILIZER MADE OF RICE-HUSK-ASH NATURAL-RUBBER CHITOSAN COMPOSITE
}

\author{
M.Adlim ${ }^{1,2}$, R.F.I. Ramayani ${ }^{2}$, I. Khaldun ${ }^{2}$, F. Muzdalifah ${ }^{2}$, \\ S. Sufardi ${ }^{3}$ and R. Rahmaddiansyah ${ }^{4}$ \\ ${ }^{1}$ Department of Mathematics and Applied Science, Graduate School, Universitas Syiah Kuala, \\ Darussalam Banda Aceh, 23111, Indonesia \\ ${ }^{2}$ Chemistry Department, FKIP Universitas Syiah Kuala, Darussalam Banda Aceh, 23111, \\ Indonesia \\ ${ }^{3}$ Soil Science Department, Faculty of Agriculture, Universitas Syiah Kuala, Darussalam, Banda \\ Aceh, 23111, Indonesia \\ ${ }^{4}$ Agribusiness Department, Faculty of Agriculture, Universitas Syiah Kuala, Darussalam Banda \\ Aceh, 23111, Indonesia \\ ${ }^{\square}$ Corresponding Author: adlim@unsyiah.ac.id
}

\begin{abstract}
Finding a formula and characterization of slow-release fertilizer made of eco-friendly materials to reduce water pollution risk has been intensively studied. This study aims to explore fertilizing properties of the new formula in urea-slow-release and urea-magnesium-slow-release fertilizers on rice (Oryza sativa L, variety of mutant inpari IR42). Stable and eco-friendly slow-release-fertilizer tablets were prepared from rice-husk-ash, liquid natural rubber, Epsom salt, and chitosan in an appropriate composition. The matrix of tablets was stable and persisted in water incubation for at least 12 days; the urea release was much slower than that from control and being comparable to the release rate in previously reported studies. The nutrient dissolution rate is in the range of plant nitrogen uptake, so that being prevented from excessive release into the environment. The Oryza sativa L absorbed the nutrient adequately indicated by high nitrogen uptake efficiency (NUE). The slow-release fertilizer significantly enhanced the number of rice tillers, leaves, panicles, and rice grain weight. The use of this slow-release fertilizer reduced nearly $75 \%$ of urea usage without reducing the grain yield.
\end{abstract}

Keywords: Oryza sativa L, Magnesium Sulfate, Slow-release Urea, Nitrogen Uptake, NUE.

RASĀYAN J. Chem., Vol. 14, No.3, 2021

\section{INTRODUCTION}

Studies on urea slow-release (USR) fertilizers have been intensively reported. The main objective is attempting to optimize nitrogen uptake by the plant and reducing the risk of water pollution. ${ }^{1-4}$ In rice cultivation using prill urea, only 38.2-44.8\% of nitrogen from urea will be absorbed by the plant, and the rest will be lost and become a source of water pollution. ${ }^{5}$ Thereby, optimizing the uses of urea also will support environmental control and also reduce the government subsidy' bill. Compare to water-soluble fertilizers; the slow-release one will be more compatible to use in various planting media, including in a floating-rice-system of flood-prone-rice-field. ${ }^{6,7}$

The common fabrication of slow-release fertilizers involved synthetic polymers and organic solvents, which then become a source of pollution, and the preparations often required complicated procedures. ${ }^{8,9}$ The pollution risk has been concerned and is being initiated to use a combination of biodegradable materials and synthetic polymers. ${ }^{10-16}$ However, there have been few reports on the preparation of chemical fertilizers encapsulated with eco-friendly materials. ${ }^{17}$

We have been studying a simple preparation and eco-friendly formula for urea slow-release fertilizer by using rice-husk-ash, sago starch, urea, and chitosan. ${ }^{18,19}$ In this study, we substituted sago starch with natural rubber (latex) since natural rubber is produced continuously in agriculture industries, cheaper and 
more compatible at room temperature and Epsom salt was used as a source of magnesium and sulfur. Magnesium sulfate (Epsom salt) and urea are easily dissolved in water and easily washed out by rain, thereby controlling their release was a crucial study. Magnesium functions as an activator of various enzymes involved in photosynthesis, respiration, and DNA and RNA reactions. ${ }^{20}$ The interaction between magnesium with natural latex-chitosan in a single composite has not been fully understood, and the fertilizing properties are being explored.

In this current study, we prepared both USR and urea magnesium slow-release (UMgSR) and characterized the composite properties. Our studies on the nutrient release pattern from urea-magnesium slow-release within the water and in soil have been reported. ${ }^{21}$ This current study is focused on the fertilizing properties and plant responses. Rice (Oryza sativa L) was chosen as a plant model to explore the effect of nutrient release on the growth parameters. ${ }^{22}$

\section{EXPERIMENTAL}

\section{Preparation of Urea-magnesium Slow-release Tablet}

The fresh rubber sap or skim latex was obtained directly from the rubber tree (Hevea brasiliensis) at Rimba Sawang Village, Tenggulun District, Aceh Tamiang, Indonesia at the coordinate of $4.1261^{\circ} \mathrm{N}$, $98.0192^{\circ}$ E. Latex $(5 \mathrm{~L})$ is filtered and mixed with $125 \mathrm{~mL}$ of $2.5 \% \mathrm{NH}_{4} \mathrm{OH}$, and kept in the refrigerator $\left(4^{\circ} \mathrm{C}\right)$ before used. The density and viscosity of latex were measured by Stokes's falling ball method and it is named liquid latex.

Preparation of urea-magnesium slow-release (UMgSR) tablets was prepared by modifying the previous procedure. ${ }^{18,19}$ Five kilograms of dry rice husk-ash were finely ground and sieved with a $0.180 \mathrm{~mm}(80$ mesh) sieve. Particles that passed through the sieve were taken and dried in an oven until constant weight. A mixture of $60 \mathrm{~g}$ of rice-husk-ash, $20.80 \mathrm{~g}$ of urea, and $9.6 \mathrm{~g}$ of $\mathrm{MgSO}_{4} \cdot 7 \mathrm{H}_{2} \mathrm{O}$ (Epsom salt) were mixed truly by using a mixer. Then $15 \mathrm{~mL}$ of the liquid latex, which was previously homogenized with $45 \mathrm{~mL}$ of water, was mixed firmly into the mixture with continuously stirring. The sample was inserted into a tablet mold with a diameter of $1.2 \mathrm{~cm}$ and $15 \mathrm{~cm}$ height, then was pressed with a hydraulic press at $100 \mathrm{Nm}^{2}$. The tablets were air drying up to 24 hours before being dried in an oven for 30 minutes at $105^{\circ} \mathrm{C}$ to reduce moisture and trace ammonia. The tablets were coated with chitosan film by soaking them for 5 minutes in chitosan solution $(0.25 \mathrm{~g}$ in $250 \mathrm{~mL}$ of $1.5 \%$ of acetic acid solution). Coated tablets were dried back in an oven for 30 minutes at $105^{\circ} \mathrm{C} .{ }^{19}$ The dried tablets were kept in a sample container and placed in a dry place. Samples were analyzed based on water content, survival time in the water, and the matrix stability in friction verified the previous $\operatorname{method}^{19}$ and analyzed the chemical interaction by Fourier Transform Infrared Spectroscopy (FTIR).

\section{Fertilizing Experiment}

An experiment on UMgSR fertilizing was conducted in a screen (net) house with a transparent roof. Laguna-round water-basins were used as pots and filled in with soil and water to mimic paddy soil in a controlled environment. The planting was controlled in the net house with a transparent roof. Rice planting started from March up to August 2018 in an area surrounded by rice fields at the coordinate of $5.5700^{\circ} \mathrm{N}, 95.3874^{\circ} \mathrm{E}$.

The soil sample was dried, filtered, and weighted before being filled in sample pots (model of lagunaround water-basins $\phi 30 \mathrm{~cm}$ ). The soil was characterized in the soil lab and analyzed the texture, Corganic, $\mathrm{N}$-total (Kjeldahl), Mg-exchangeable, $\mathrm{C} / \mathrm{N}$ ratio $^{23}$, $\mathrm{CEC}\left(\mathrm{NH}_{4} \mathrm{OAC} \mathrm{pH} \mathrm{7),} \mathrm{and} \mathrm{soil} \mathrm{pH}\right.$ (Electrometrics). The paddy soil was prepared in 30 laguna-round water basins by filling in with $5 \mathrm{~kg}$ dried soil and $3 \mathrm{~L}$ of water. The experimental design was a randomized complete block design (RCBD), 4 $\mathrm{x} 4$ factorial with three replications, and each replication comprised a single plant. Data were compared among the type of fertilizers, doses, and observation time interval by ANOVA two factors (the type of fertilizers and doses). Further analysis was conducted by Fischer's Least Significant Difference (LSD) at level confidence of $\mathrm{P} \leq 0.05$. Fertilizer factors were $\mathrm{P} 0$ (no urea; control-1), $\mathrm{P} 1$ ( $2 \mathrm{~g}$ of prill urea per plant, which is a standardized dose for traditional fertilization, control-2), the urea within the slow-release tablet is shown in Table-1. Refer to traditional rice cultivation, we set a maximum of $2 \mathrm{~g}$ (control-2) of prill urea per plant, and then doses were set gradually decreased in treatment factors. Rice seeds were superior 
RASĀYAN J. Chem.

Vol. 14 | No. 3 |1851-1859| July - September | 2021

mutant varieties (inpari IR-42; 100-112 harvest days), which were obtained from the Agriculture Department, the Republic of Indonesia, with certified quality. The seeding process was started by soaking the seed in water. Float seeds are removed, while the sunk ones were immersed in water for 12 hours.

Table-1: Experimental Design for Slow-release Fertilizer Studies on Oryza Sativa L Growth

\begin{tabular}{l|l|l|l|c}
\hline Remarks* & Urea $(\mathrm{g})$ & $\begin{array}{l}\mathrm{MgSO}_{4} . \\
7 \mathrm{H}_{2} \mathrm{O}(\mathrm{g})\end{array}$ & Codes & Replications \\
\hline Control-1 & 0 & 0 & $\mathrm{P} 0$ & 3 \\
\hline Control-2 & 2 & 0 & $\mathrm{P} 1$ & 3 \\
\hline \multirow{5}{*}{ Urea SR } & 0.495 & 0 & $\mathrm{P} 2 \mathrm{M} 1$ & 3 \\
\cline { 2 - 5 } & 0.990 & 0 & $\mathrm{P} 2 \mathrm{M} 2$ & 3 \\
\cline { 2 - 5 } & 1.485 & 0 & $\mathrm{P} 2 \mathrm{M} 3$ & 3 \\
\cline { 2 - 5 } & 1.980 & 0 & $\mathrm{P} 2 \mathrm{M} 4$ & 3 \\
\hline \multirow{5}{*}{ UMgSR } & 0.495 & 0.23 & P3M1 & 3 \\
\cline { 2 - 5 } & 0.990 & 0.46 & P3M2 & 3 \\
\cline { 2 - 5 } & 1.485 & 0.69 & P3M3 & 3 \\
\cline { 2 - 5 } & 1.980 & 0.92 & P3M4 & 3 \\
\hline
\end{tabular}

*To all plants per pot is given $0.25 \mathrm{~g} \mathrm{KCl} \& 0.325 \mathrm{~g}$ TSP (triple superphosphate, containing $46 \%$ of $\mathrm{P}_{2} \mathrm{O}_{5}$ )

Then the wet seeds were kept in a humid container to generate sprouts and then spread evenly in the soil media covering with a mosquito net. After 10 days, the rice tillering was selected to obtain all were in similar size before being transplanted in experimental pots. Each pot grew a single plant, and each treatment has 3 replications. The pots were marked and were randomly placed with $30 \mathrm{~cm}$ space between pots. The place was rearranged every week, and the level of water was maintained at constant volume every day by adding water. All plants were placed in a net house with a transparent roof (the size; $4 \mathrm{~m} \mathrm{x} 4$ m x 2.5 m). Transplanting was started on 28 April 2018 and harvested on 12 August 2018.

\section{Rice Response on Slow-release Fertilizer}

Observation of rice growth was carried out every interval of 15 days after transplanting (DAT), and several parameters including column height, number of tillers, and number of leaves up to age 84 DAT (during vegetative to generative phase transitions), the number panicles, and weight of rice grain were recorded. ${ }^{24}$ The column height is measured from the base of the root to the point where the leaves grow. The column diameter is measured at a distance of $5 \mathrm{~cm}$ from the base of the root using a caliper. ${ }^{25}$

\section{Determination of Nitrogen Release in Water, the Soil, and the Plant}

The water level in pots was maintained at constant volume, and $5 \mathrm{~mL}$ of water in each experiment pot was sampled at an interval of 6 DAT, 12 DAT, and 18 DAT. Nitrogen content in each sample was determined by UV-Vis spectrophotometry (UVmini-1240, Shimadzu, Japan) method at $400 \mathrm{~nm}$ using Nessler reagent as the complexing agent. Ten grams of soil from each pot were sampled at intervals of 6 DAT, 50 DAT, and the day after harvesting (DAH) or day 109. The dried plant was sampled and treated with several procedures and analyzed by using Kjeldahl methods at the Soil Laboratory of Agriculture Department, Universitas Syiah Kuala. Total N in plant and soil was determined by using Kjeldahl methods. ${ }^{26}$

\section{Urea Slow-Release Properties}

\section{RESULTS AND DISCUSSION}

Two types of slow-release fertilizers were prepared that were USR fertilizer (P2 group) and urea magnesium slow-release (UMgSR) fertilizer (P3 group). Every $60 \mathrm{~g}$ of the composite gave 42 tablets, and each tablet contained $0.495 \mathrm{~g}$ of urea. Similar doses of urea were used to prepare UMgSR, and each tablet contained $0.23 \mathrm{~g}$ of $\mathrm{MgSO}_{4} \cdot 7 \mathrm{H}_{2} \mathrm{O}$. The skim latex used has density of $0.962 \mathrm{~g} / \mathrm{cm}^{3}$ and viscosity is $0.60 \mathrm{~g}$ $. \mathrm{cm} / \mathrm{s}$ or $60 \mathrm{cP}$ at $27^{\circ} \mathrm{C}$. All tablets were coated with chitosan film. The composite was easily shaped look like tablets with dimensions of $1 \mathrm{~cm}$ height and $1 \mathrm{~cm}$ of diameter. The tablet was stable and persisted in water incubation for at least 12 days; the water content was $21 \pm 0.3 \mathrm{wt} \%$ and survived from fungus attack in a month, the finding verified the previous report. ${ }^{19}$ 
The surface of the tablet was represented by the SEM image, as shown in Fig.-1(a), the liquid natural rubber coagulated urea, magnesium sulfate, and rice husk-ash were in the form of fragments that allow water to penetrate and dissolve slowly of the chemicals. The fragments were in irregular shapes with various sizes; some were between 20 and 50 microns.

Attempting to search for chemical interaction in composite was conducted by using FTIR methods. However, the FTIR spectra, as shown in Fig.-1(b) displayed some representative bands, which are at $3500-800 \mathrm{~cm}^{-1}$ in, and some of the areas categorized as a fingerprint zone are not shown here because they will not contribute specific information.

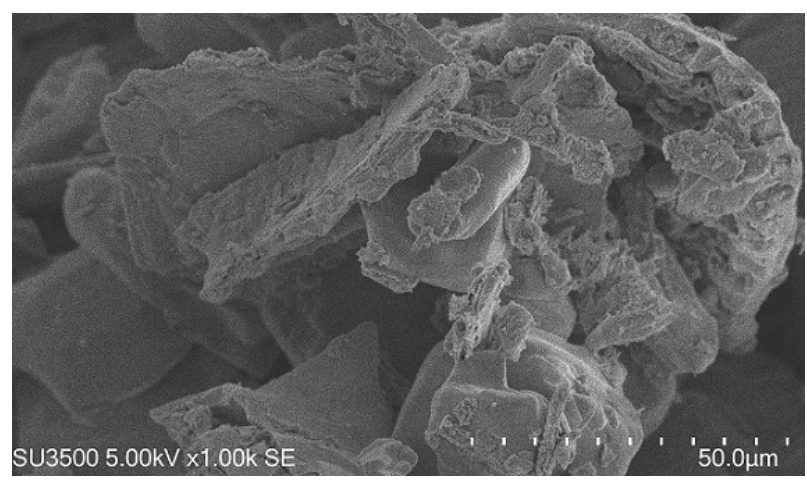

(a)

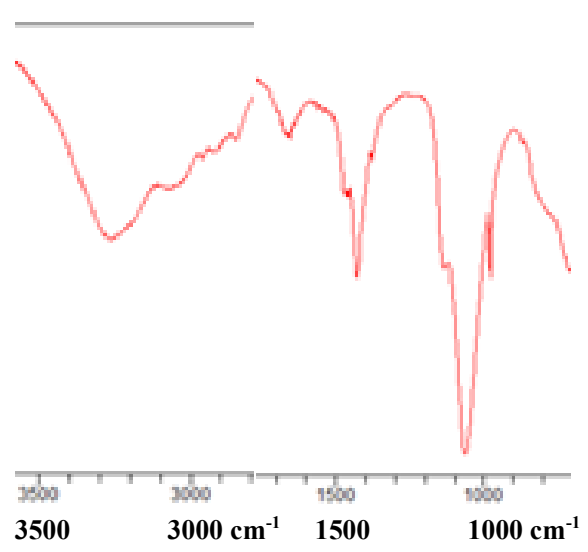

(b)

Fig.-1: (a) Representative SEM image of Slow-release Fertilizer; (b) Cropped FTIR Spectra of Composite Slowrelease Fertilizer Natural-rubber-chitosan-urea- $\mathrm{MgSO}_{4} \cdot 7 \mathrm{H}_{2} \mathrm{O}$

The sensitivity was very low; then, it is difficult to determine the characteristic bands because the many modes of stretching and bending overlapped, where is likely to find spectra of metal $(\mathrm{Mg})$ interaction. The recorded FTIR spectra show a broad and strong band in the area of 3400-3200 $\mathrm{cm}^{-1}$ that might represent the $-\mathrm{OH}$ and $-\mathrm{NH}_{2}$ from the chitosan structure ${ }^{27}$ and overlapped with a functional group of urea if it is compared urea-magnesium spectra. ${ }^{28}$ The Carbonyl group from urea might be represented by a sharp band at $1600 \mathrm{~cm}^{-1}$ as confirm from the individual spectrum. The functional group of $\mathrm{S}=\mathrm{O}$ from magnesium sulfate might be indicated by the existing band at $1050 \mathrm{~cm}^{-1}$ in all spectra Fig.-1(b). ${ }^{29}$ Isoprene structure of natural rubber might be represented by a double band of $2918-2850 \mathrm{~cm}^{-1}$ but weak intensity as shown in Fig.-1(b). ${ }^{30}$ We have reported earlier the detailed characteristic slow-release properties of UMgSR fertilizer, including the release rate compared to the dissolution rate of commercial chemical fertilizers. The nutrient release of UMgSR rate was generally slower than the dissolution rates of related commercial slow-release fertilizers. ${ }^{21}$

\section{Soil Characteristics}

The soil texture of the planting media includes clay content, silt, and sand. The laboratory data show clay content (5\%), silt (69\%), sand (26\%), $\mathrm{pH}(8), \mathrm{N}$ total (0.23\%), C-organic $(0.18 \%), \mathrm{C} / \mathrm{N}(0.78), \mathrm{CEC}(36.8$ $\left.\mathrm{cmol}_{(+)} \mathrm{kg}\right)$ and $\mathrm{Mg}$-exchangeable $(0.32 \mathrm{cmol} / \mathrm{kg})$. The soil characteristics are considered as sandy clay (Sandy-clay-loam), which is appropriate for growing rice. It was rather alkaline soil with minimum availability of $\mathrm{N}$ in the soil. This is consistent with $\mathrm{N}$ total content, which is only $0.23 \%$ as common in basic soil ( $\mathrm{pH} 8$ ). Based on the $\mathrm{pH}$ and $\mathrm{N}$ values in the soil, the soil is considered sufficient in supplying $\mathrm{N}$ for plant growth. The $\mathrm{C}$ organic and $\mathrm{C} / \mathrm{N}$ ratios were $0.18 \%$ and 0.78 , respectively, which are both classified as very low. The ratio is less than 20 indicates that $\mathrm{N}$ mineralization was due to decomposer microbes. Mineralization is the process of reforming organic compounds into inorganic so that nutrients become more available in the soil. ${ }^{31}$ The Cation Exchange Capacity (CEC) was $36.8 \mathrm{cmol}_{(+)} \mathrm{kg}$, which is classified as high and healthy soil. The CEC values are influenced by soil properties such as soil $\mathrm{pH}$, texture, and organic matter. This is verified the theory that a low CEC $(<17 \mathrm{cmol} / \mathrm{kg})$ is unhealthy, a range of $18-25 \mathrm{cmol} / \mathrm{kg}$ is categorized as poor soil, and a high CEC ( $>25 \mathrm{cmol} / \mathrm{kg})$ is considered healthy soil. ${ }^{32}$ 
RASĀYAN J. Chem.

Vol. 14 | No. 3 |1851-1859| July - September | 2021

The exchangeable base cations in the soil, represented by $\mathrm{Mg}^{2+}$ was $0.32 \mathrm{cmol}_{(+)} / \mathrm{kg}$ is classified very low. This condition is caused by the constituent minerals of the soil, which are poor in basic cations; it is washed out by high rainfall, etc.

\section{Nitrogen Release}

Urea concentration within plant media (water and soil) released from the fertilizer (prill urea, USR, or UMgSR tablets) was analyzed periodically. The volume of water was maintained constant by the addition of water at a constant level. The water was sampled at 6,12, and 18 DAT to determine the total N found in water, as shown in Fig.-2(a). There is a significant enhancement of $\mathrm{N}$ release at each control and treatment media during the observation time interval (6-18 DAT). $\mathrm{N}$ release differences between treatments and control were also significant but only at $6 \mathrm{DAT}$, according to $\operatorname{LSD}_{0.05}(F=13.38, d f=9)$, and none for other observation of time intervals. $\mathrm{N}$ found in P1 pot was the highest compared to other treatment pots. However, at 12 and 18 DAT the differences within fertilizer types are no longer significant because prill urea in $\mathrm{P} 1$ drastically decreased after 12 days of incubation time, indicating the $\mathrm{N}$ excessive release. The reverse release pattern was observed in slow-release fertilizer groups (P2 \& P3), which $\mathrm{N}$ slowly and continuously release in water. Increasing urea doses in urea slow-release fertilizer (P2) causes more urea release in water, but such a trend was not observed in P3, in which the rate was not significantly different among P3 treatments. This might be the effect of both magnesium and chitosan in the composite (P3), which retard the $\mathrm{N}$ nitrogen release rate as previously reported. ${ }^{21}$ The dissolution rate (DR) of this SR-urea tablet $(0.11 \pm 0.09 \mathrm{ppm}$ or $0.5 \mathrm{wt} \%$ per day $)$ is slower than DR of both commercial slow-release urea and polymer-coated-sulfur-coated urea (PCSU). PCSU releases urea up to 30-60\% in 7 days of incubation. ${ }^{33}$ The DR of prill urea was much faster, which is $75 \mathrm{wt} \%$ loss in $>0.5 \mathrm{~h} .{ }^{34,35}$ The slower release is preferable to provide nutrients for the plants to be absorbed and to prevent water pollution. The rate of urea release in this study is considered slow since the standardized slow-release urea was less than $15 \%$ in $24 \mathrm{~h}$ or $<75 \%$ release in 28 days. ${ }^{8}$ Nitrogen was deposited in the soil, converted to ammonia, and then nitrate before being absorbed by the plant. The amount of nitrogen retained in the soil was sampled and presented in Fig.-2(b). At the beginning (6 DAT), there was no significant difference amount of $\mathrm{N}$ found among treatment pots. This indicates that the excessive urea release from prill urea (control-2 or P1) was only partially absorbed by soil, and some were released into the environment. After 50 day of transplanting, slow-release fertilizer groups (P2 \& P3) releases $\mathrm{N}$ significantly higher $(\alpha=0.05, F=0.354, \mathrm{df}=9)$ into the soil compared to the control group (P1). However, at harvest time (day 109 DAT), nitrogen content found in the soil media at all types of fertilizers was no longer significantly different.

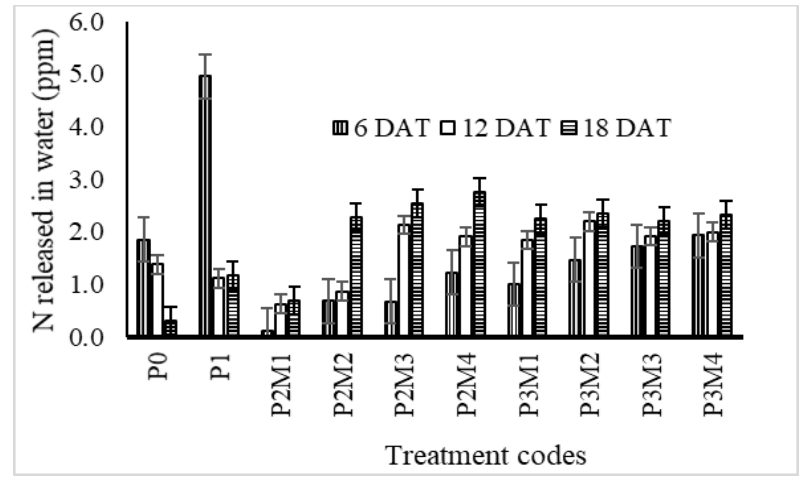

(a)

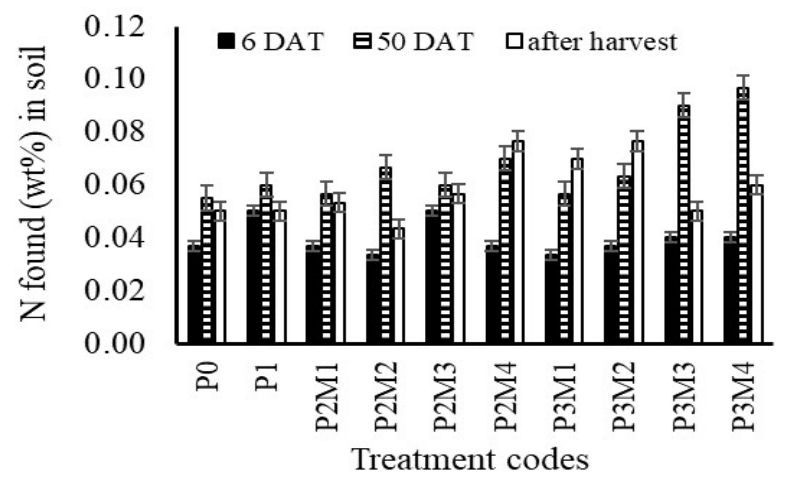

(b)

Fig.-2: (a) Mean Nitrogen release in Water (Plant Media), (b) in Soil Media; sampled at various DAT (P1: prill

Urea Pots; P2: USR Group; P3: UMgSR Group. DAT = days after transplanting; USR = Urea Slow Release; $\mathrm{UMgSR}=$ Urea Magnesium Slow Release; P0 = No Fertilizer, P1 = $2 \mathrm{~g}$ of Urea; P2M1-P2M4 $=(0.495-1.980)$ of $\mathrm{g}$ Urea; P3M1-P3M4 $=(0.495-1.980) \mathrm{g}$ of Urea $+(0.23-0.92) \mathrm{g}$ of Epsom Salt. 
RASĀYAN J. Chem.

Vol. 14 | No. 3 |1851-1859| July - September | 2021

\section{Rice Plant responds to New Slow-release Fertilizers}

Rice's response to the fertilizers was deduced from several parameters that were the column (rice strew) height, the number of tillers, and leaves. Significant rice-column growth was observed in all treatments, and there was no significant difference in the column height among treatments (at sig. of $0.05 \%$ ). Still, there is a significant difference among observation time intervals as shown in Fig.-3(a). This implied that magnesium had no significant effect on the column height. A similar case was also previously reported on tomato plants that were no different effects on the height either fertilized by magnesium ammonium phosphate or the controlled release fertilizer ${ }^{36}$. Contrast differences from controls were on the number of rice tillers, leaves, and mean weight of grain. Significantly $\left(\mathrm{LSD}_{0.05} ; F=4.87 \mathrm{df}=9\right)$ much more tillers, more leaves (LSD ${ }_{0.05} ; F=3.12 ; d f=9$ ) and more grains (were observed in slow-release treatment pots (P2 \& P3) as shown in Table-2. Unlike column height, both tillers and leaves were significantly enhancement by magnesium sulfate; this is supported by the theory that sulfur has been recognized as a nutrient for rice tiller development. ${ }^{37}$

By using the nonparametric Kruskal-Wallis Test $(\mathrm{H}=26.34$, $\mathrm{df}=9$, sig. $<0.05)$, and PostHoc by Mann Whitney $\mathrm{U}$ Test, there is a significantly different mean of tillers number among plots. The tillers increase significantly as the effect of slow-release fertilizer. Using the statistical method $(\mathrm{H}=4.97, \mathrm{df}=9$, sig. $=$ 0.05 ) found that there is no significant different mean of grain weight per panicle in the treated experiment. The weight of grain did not reduce per panicle, although the fertilizer doses have been reduced up to $75 \%$ in slow-release fertilizer content. The number of tillers and leaves in the P3 group was higher than in the P2 group, especially at the M4 level. The grain yield of rice was reported to increase because magnesium enhanced the nitrogen uptake by the plant. ${ }^{38}$ Enhancement of rice tillers usually causes more rice leaves and grain yield. Another growth parameter was deduced from the number of rice panicles per clump that was described in Fig.-3(b). Consistent enhancement of panicles along with the increasing of fertilizer doses occurred in the USR and UMgSR treatment pots, but magnesium had no significant effect on the panicle enhancement. The weight of 1000 rice grains in all treatments was nearly uniform, that was $24.5 \pm 0.5 \mathrm{~g}$, which is considered normal grains for this rice mutant variety. ${ }^{39}$ The total grain weight prediction; in P1 experiment code P1 (2 g per plant of prill urea) is 2.64 ton/ ha. In P2 group (0.25-2.00 g of slow-release urea) treatment, the mean yield is $5.69 \mathrm{ton} / \mathrm{ha}$. The yield in P3 group experiment (0.25-2.00 $\mathrm{g}$ of slow-release urea $+0.23-0.92 \mathrm{~g}$ of Epsom salt) is $5.35 \mathrm{ton} / \mathrm{ha}$.

Table-2: Growth parameters and the yield

\begin{tabular}{c|c|c|l|l|c}
\hline $\begin{array}{l}\text { Sample } \\
\text { Codes }\end{array}$ & $\begin{array}{l}\text { Mean } \\
\text { Tillers* }\end{array}$ & $\begin{array}{l}\text { Mean of } \\
\text { Panicles* }\end{array}$ & $\begin{array}{l}\text { Mean Grain } \\
\text { per Panicles } \\
(\mathrm{g})\end{array}$ & $\begin{array}{l}\text { Mean } \\
\text { Leaves } \\
\text { Number* }\end{array}$ & $\begin{array}{l}\text { Weight } 1000 \\
\text { Grains** }(\mathrm{g})\end{array}$ \\
\hline P0 & $6.0 \pm 2$ & $6.0 \pm 1$ & $142.5 \pm 23$ & $15.7 \pm 3$ & $23.75+1$ \\
\hline P1 & $12.0 \pm 4$ & $9.7 \pm 2$ & $244.8+40$ & $35.7 \pm 11$ & $25.19+1$ \\
\hline P2M1 & $9.3+2$ & $10.3 \pm 1$ & $260.4+40$ & $37.3+8$ & $25.19+1$ \\
\hline P2M2 & $18.3 \pm 3$ & $13.3 \pm 1$ & $337.5 \pm 24$ & $63.0 \pm 10$ & $25.35+1$ \\
\hline P2M3 & $21.7 \pm 3$ & $16.3 \pm 1$ & $407.1+36$ & $70.0 \pm 6$ & $24.95+2$ \\
\hline P2M4 & $17.0 \pm 5$ & $17.3 \pm 0$ & $428.9 \pm 8$ & $50.3 \pm 10$ & $24.76+0$ \\
\hline P3M1 & $11.3 \pm 1$ & $10.7 \pm 1$ & $262.9 \pm 41$ & $40.7 \pm 8$ & $24.57+1$ \\
\hline P3M2 & $15.3+4$ & $11.3 \pm 0$ & $280.9 \pm 13$ & $53.7 \pm 10$ & $24.80+1$ \\
\hline P3M3 & $23.3 \pm 1$ & $16.7 \pm 1$ & $428.1+51$ & $79.0+10$ & $25.65+2$ \\
\hline P3M4 & $27.0 \pm 8$ & $17.0 \pm 0$ & $412.5 \pm 28$ & $87.5+16$ & $24.27+2$ \\
\hline *after 45 DAT; $* *$ harvesting time;
\end{tabular}

The total nitrogen found in the whole rice plant from all treatments was not significantly different except with control $(\mathrm{P} 0)\left(\mathrm{LSD}_{0.05}\right)$. This finding is comparable with the previous report on rice $\mathrm{N}$ uptake. ${ }^{40} \mathrm{~A}$ significant difference in terms of nitrogen uptake efficiency (NUE) was observed among treatment samples. NUE was calculated by determining the total nitrogen in the experimental sample, subtracted with control, and then divided by nitrogen doses. The highest NUE was found in the least urea content in slow-release fertilizers. The highest NUE was $69.53 \%$ in P2M1, and $88.05 \%$ in P3M1 samples, which is 
RASĀYAN J. Chem.

Vol. 14 | No. 3 |1851-1859| July - September | 2021

comparable to the previous report of rice NUE. ${ }^{41}$ NUE in treatment samples is much higher than the NUE in control-2 (P1), which is only $18.88 \%$. Thereby using slow-release fertilizer will improve the efficiency of using urea and will reduce environmental risk.

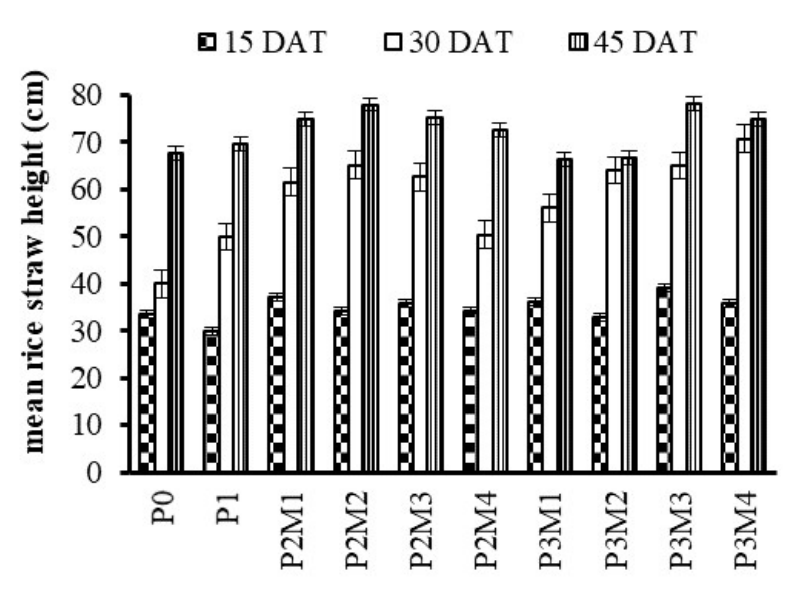

Treatment codes

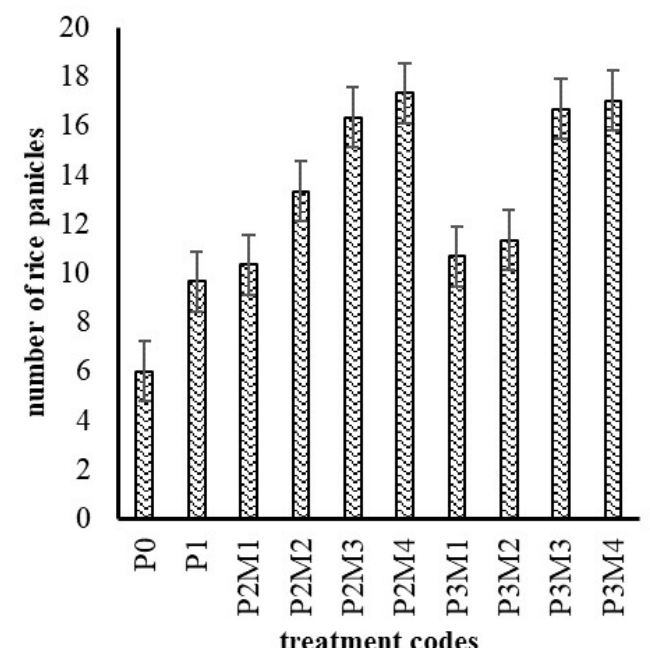

(b)

Fig.-3: Growth Parameters; (a) Mean Rice Straw and (b) Mean Number of Rice Panicles

\section{CONCLUSION}

Stable tablets of urea slow-release and urea magnesium slow-release have been fabricated from rice-huskash, liquid natural rubber, and chitosan composite. Urea release in water (planting media) from treated fertilizer tablets was much slower than from control at the beginning of planting time. Still, at a longer time, slow-release fertilizer has a higher dissolution rate than that of control. In slow-release group treatment, the equivalent rate was observed at various doses of fertilizer. Different amount $\mathrm{N}$ absorbed by soil was found at 50 days after planting; there was no obvious difference at the beginning and after harvesting time. These slow-release fertilizers significantly enhanced the number of leaves, tillers, panicles, and grain weight of Oryza sativa L. The nitrogen uptake efficiency was considered high compared to previously reported studies. The slow-release fertilizers reduced the use of urea up to $75 \%$ without degrading the rice yield. The new fertilizer will prevent water pollution, lessen government subsidy bills to the farmers and gain some economic benefit. The nutrient release experience was carried in paddy soil; it might be interesting to study the fertilizing properties in dry planting media.

\section{ACKNOWLEDGEMENT}

We would like to express our appreciation to Universitas Syiah Kuala, Banda Aceh, Indonesia for providing a research grant with registration number: 287/UN11/SP/PNBP/2018, 29 January 2018.

\section{REFERENCES}

1. Y. Xiang, J. Ji-yun, H. Ping and L. Ming-Zao, Journal of Agricultural Sciences in China, 7, 469(2008), https://doi.org/10.1016/S1671-2927(08)60091-7

2. J. Wang, S. Liu, Y. Qin, X. Chen, R. Xing, H. Yu, K. Li and P. Li, Chinese Journal of Ocean Limnology, 35, 1036 (2017), https://doi.org/10.1007/s00343-017-6074-9

3. W. Faishol, D. Rubiyanto, L. Chuenchom and I. Fatimah, Rasayan Journal of Chemistry, 12(4), 1792(2019), http://dx.doi.org/10.31788/RJC.2019.1245386

4. J. Jayanudin and R. S. D. Lestari, Rasayan Journal of Chemistry, 13(2), 1074(2020), http://dx.doi.org/10.31788/RJC.2020.1325572

5. M.M. Rahman, A. Ahsan, M.A.M Salleh, M.M. Hossain, C.S. Ra and U. Rashid, Arabian Journal of Chemistry, 7, 139(2014), https://doi.org/10.1016/j.arabjc.2013.10.007

6. H. Irianto, E. Mujiyo, W. Riptanti and A. Qonita, IOP Conference Series: Earth Environmental Sciences, 142, 012072(2018), https://doi.org/10.1088/1755-1315/142/1/012072 
RASĀYAN J. Chem.

Vol. 14 | No. 3 |1851-1859| July - September | 2021

7. Q. Kang, R. Li, Q. Du, B. Cheng, Z. Liao, C. Sun and Z. Li, BioMedical Research International, 3856386, 1 (2016), https://doi.org/10.1155/2016/3856386

8. M.Y. Naz and S.A. Sulaiman, Journal of Control Release, 225, 109(2016), https://doi.org/10.1016/j.jconrel.2016.01.037

9. B. Azeem, K. KuShaari, Z.B. Man, A. Basit and T.H. Thanh, Journal of Control Release, 181, 11(2014), https://doi.org/10.1016/j.jconrel.2014.02.020

10. T. Jamnongkan and S. Kaewpirom, Journal of Polymers Environment 18, 413(2010), https://doi.org/10.1007/s10924-010-0228-6

11. T. Jamnongkan and S. Kaewpirom, Science Journal of Ubon Ratchathani University, 1,43(2010), https://doi.org/10.1007/s10924-010-0228-6

12. M.A. Khan, W. Mingzhi, B.K. Lim and J.Y. Lee, Journal of Wood Science, 54, 158(2008), https://doi.org/10.1007/s10086-007-0924-6

13. L. Xie, M. Liu, B. Ni, X. Zhang and Y. Wang, Chemical Engineering Journal, 167, 342(2011), DOI: https://doi.org/10.1016/j.cej.2010.12.082

14. A.E. Al-Rawajfeh, E.M. AlShamaileh and M.R. Alrbaihat, Journal of Indian Engineering Chemistry, 73, 336(2019), https://doi.org/10.1016/j.jiec.2019.01.046

15. M.R. Hussain, R.R. Devi and T.K. Maji, Iranian Polymer Journal, 21, 473(2012), https://doi.org/10.1007/s13726-012-0051-0

16. B. Xianyang, L. Hongsheng, J. Zhili, C. Ling, X. Xiaoming, Y. Long and X. Fengwei, Chemical Engineering Journal, 309, 607(2017), https://doi.org/10.1016/j.cej.2016.10.101

17. I. Munaweeraa, A. De Alwisf, V. Karunaratnea, G.A.J Amaratungaa, N. Madusankaa, C.Sandaruwana, N. Kottegodaa and D. Sirisenae, Applied Clay Science. 15, 303(2017), https://doi.org/10.1016/j.clay.2017.09.039

18. M. Adlim, F. Zarlaida, Z. Zuraida and D. Darusman, Pakistan Journal of Life and Social Sciences, 16, 20(2018)

19. M. Adlim, F. Zarlaida, R.F.I. Rahmayani and R. Wardani, IOP Confererence Series: Material Science Engineering, 380, 012010(2018), https://doi.org/10.1088/1757-899X/380/1/012010

20. W. Guo, H. Nazim, Z. Liang and D. Yang, Crop Journal, 4, 83(2016), https://doi.org/10.1016/j.cj.2015.11.003

21. M. Adlim, F. Zarlaida, R.F.I. Rahmayani and R. Wardani, Environmental Technology \& Innovation 16, 100442(2019), https://doi.org/10.1016/j.eti.2018.10.011

22. W. Hai-yan, C. Zhi-feng, X. Zhi-peng, Z. Lei, L. Qiu-yuan, Z. Zhen-zhen, J. Yan, H. Ya-jie, Z. Jinyan, C. Pei-yuan, D. Qi-gen and Z. Hong-cheng, Journal of Integrative Agriculture, 17, 2222(2018), https://doi.org/10.1016/S2095-3119(18)62052-0

23. N.H. Batjes, ISRIC Report 2002/02c. International Food Policy Research Institute (IFPRI) and International Soil Reference and Information Center (ISRIC), Wageningen, (2002)

24. A. Triadati, P. Akbar and S. Sarlan. Buletin Anatomi dan Fisiologi, 20, 1(2012)

25. S. Karki, N.S. Poudel, G. Bhusal, S. Simkhada, B.R. Regmi, B. Adhikari and S. Poudel, World Journal of Agricultural Research, 6, 58(2018), https://doi.org/10.12691/wjar-6-2-4

26. D.W. Nelson and L.E. Sommers, Journal of the Association of Official Analytical Chemists, 63(4), 770(1980), https://doi.org/10.1093/jaoac/63.4.770

27. V. Sathiyanarayanan, H. Venkatasubramanian and D. Easwaramoorthy, Rasayan Journal of Chemistry, 12(4), 2141(2019), http://dx.doi.org/10.31788/RJC.2019.1245419

28. H. Staroszczyk, K. Sztuka, J. Wolska, A. Wojtasz-Paja and I. Kołodziejska, Spectrochimica Acta Part A: Molecular and Biomolecular Spectroscopy, 117, 707(2014), https://doi.org/10.1016/j.saa.2013.09.044

29. F. Ovalles, M. Gallignani, R. Rondón, M.R. Brunetto and R. Luna, Latin American Journal of Pharmacy, 8, 173(2009)

30. S. Rolere, S. Liengprayoon, L. Vaysse, J. Sainte-Beuve and F. Bonfils, eXPRESS polymer Letters, 10, 408(2016), https://doi.org/10.3144/expresspolymlett.2016.38

31. K.A., Hanafiah, 2010. Dasar-dasar Ilmu Tanah [Fundamental of Soil Science], Raja Grafindo Persada, Jakarta. 
RASĀYAN J. Chem.

Vol. 14 | No. 3 |1851-1859| July - September | 2021

32. R.R. Lantoi, S. Darman and Y.S. Patadungan, Journal of Agroland, 23, 243(2016)

33. N. Xiaoyu, W. Yuejin, W. Zhengyan, W. Lin, Q. Guannan and Y. Lixiang, Biosystems Engineering, 115, 274(2013), https://doi.org/10.1016/j.biosystemseng.2013.04.001

34. S.I. Sempeho, H.T. Kim, E. Mubofu and A. Hilonga, Advance in Chemistry, 2014, 1(2014), https://doi.org/10.1155/2014/363071

35. M.H. Kabir, N.M. Talukder, M.J. Uddin, H. Mahmud and B.K. Biswas, Journal of Environmental Science Natural Resources, 4, 83(2011)

36. T.M.A. Choudhury and Y.M. Khanif, Journal of Plant Nutrition, 24, 855(2001), https://doi.org/10.1081/PLN-100103778

37. A. Ram, D. Kumar and N. Singh, Indian Journal of Agronomy, 59, 404(2014), https://doi.org/10.22438/jeb/38/4/MS-275

38. https://www.litbang.pertanian.go.id/varietas/1206/ (retrieved 25 June, 2019)

39. J.C. Cole, M.W. Smith, J. Chad, C. J. Penn, B.S. Cheary and K.J. Conaghan, Scientia Horticulturae, 211, 420 (2016), https://doi.org/10.1016/j.scienta.2016.09.028

40. M.M. Hashim, M.K. Yusop, R. Othman and S.A. Wahid, Rice Science, 22, 250(2015), https://doi.org/10.1016/j.rsci.2015.09.005

[RJC-6091/2020] 